\title{
Problemy hematologiczne w okresie ciąży
}

\author{
Hematologic complications during pregnancy
}

\author{
Izabella Kopeć \\ Poradnia Hematologiczna dla Kobiet w Ciąży, Instytut Hematologii i Transfuzjologii, Warszawa
}

\begin{abstract}
Streszczenie
Niedokrwistość i matoptytkowość czesto wystęuja w czasie ciaży. Szacuje się, że na świecie u $38 \%$ kobiet w ciaży stwierdza sie niedokrwistość, a u 7-12\% matoplytkowość. Choroby nowotworowe sa druga najczestsza przyczyna zgonów kobiet w wieku rozrodczym i wiktaja przebiegjednej na 1000 ciaz. Spośród nowotworów hematologicznych $w$ okresie ciaży najcześciej rozpoznaje sie chtoniaki (1: 1000-6000) i biataczki (1: 75 000-100 000). W artykule przedstawiono problemy zwiqzane $z$ diagnostyka i leczeniem niektórych chorób hematologicznych wystepujacych w okresie ciaży.
\end{abstract}

Słowa kluczowe: ciąża, niedokrwistość, małopłytkowość, białaczka, chłoniak

Hematologia 2016; 7, 4: 295-302

\begin{abstract}
Anemia and thrombocytopenia in pregnancy are common health problems. It is estimated worldwide that the prevalence of anemia in pregnancy is around 38\%, whilst thrombocytopenia occurs in 7-12\% of all pregnancies. Malignancy is the second most frequent cause of mortality during childbearing years and is a complication in up to 1 out of every 1000 pregnancies. The most common hematologic malignancies associated with pregnancy are lymphomas (1: 1000-6000) and leukemias (1: 75 000-100 000). This paper is a detailed review in the diagnosis and management of benign or malignant hematologic disorders whenever occurring during pregnancy.
\end{abstract}

Key words: pregnancy, anemia, trombocytopenia, leukemia, lymphoma

Hematologia 2016; 7, 4: 295-302

\section{Wprowadzenie}

W czasie prawidłowo przebiegającej ciąży dochodzi do wielu zmian dotyczących zarówno układu krwiotwórczego, jak i układu krzepnięcia. Zwiększenie objętości osocza o 40-60\% i masy erytrocytarnej o 18-25\% w stosunku do wartości sprzed ciąży powoduje obniżenie stężenia hemoglobiny do $10,5-11,0 \mathrm{~g} / \mathrm{dl}$ i wartości hematokrytu do 30-32\%. Hemodylucja jest najbardziej nasilona między 17 . a 36. tygodniem ciąży (t.c.). W wyniku zwiększonej aktywności hormonalnej (m.in. dodatkowa synteza glikokortykosteroidów przez łożysko) i syntezy cy- tokin (w tym czynnika wzrostu kolonii makrofagów i granulocytów), liczba krwinek białych wzrasta o $20 \%$. U $1 / 4$ kobiet w obrazie odsetkowym krwinek białych stwierdza się obecność pojedynczych form młodszych - mielocytów i metamielocytów. Liczba płytek krwi (PLT, platelets) zmniejsza się o 10-20\% wartości sprzed ciąży. Prawdopodobnie jest to spowodowane zwiększonym rozpadem PLT w krążeniu łożyskowym, zwiększoną sekwestracją śledzionową, hemodylucją i zależnym od hormonów zmniejszeniem ich produkcji $[1,2]$.

Zmiany dotyczące układów krzepnięcia i fibrynolizy charakteryzują się $z$ jednej strony wzrostem

Adres do korespondencji: Izabella Kopeć, Poradnia Hematologiczna dla Kobiet w Ciąży, Instytut Hematologii i Transfuzjologii, ul. Chocimska 5, 00-957 Warszawa, tel. 223496 656, faks 223496 608, e-mail: ikopec@ihit.waw.pl 
syntezy fibrynogenu, czynników krzepnięcia VII, VIII, X, czynnika von Willebranda, tkankowego aktywatora plazminogenu (t-PA, tissue plasminogen activator) i aktywatora typu urokinazy (u-PA, urokinase plazminogen activator), $\mathrm{z}$ drugiej zaś zwiększoną aktywnością inhibitora aktywatora plazminogenu typu 1 i pochodzącego $z$ łożyska inhibitora aktywatora plazminogenu typu 2. Stężenia czynników XIII i białek C i S ulegają zmniejszeniu. Efektem tych zmian jest stan nadkrzepliwości sprzyjający powstawaniu powikłań zakrzepowych. Zaistniałe w czasie ciąży zmiany ulegają cofnięciu w okresie połogu [1,2].

\section{Niedokrwistość}

Zgodnie $z$ definicją Światowej Organizacji Zdrowia (WHO, World Health Organization) za niedokrwistość patologiczną u kobiet w ciąży uznano stężenia hemoglobiny poniżej $11,0 \mathrm{~g} / \mathrm{dl}$ i hematokrytu poniżej 33\% w I i III trymestrze, w II trymestrze zaś wartości, odpowiednio, poniżej $10,5 \mathrm{~g} / \mathrm{dl}$ i $32 \%$. U kobiet, u których stężenie hemoglobiny jest obniżone do 8,0-9,9 g/dl, ryzyko urodzenia dziecka $z$ niską masą urodzeniową i porodu przedwczesnego jest znacząco wyższe niż u kobiet, u których wartość hemoglobiny utrzymuje się w granicach 10,0-11,9 g/dl [3].

W około $81 \%$ przypadków przyczyną niedokrwistości jest niedobór żelaza. W czasie ciąży wchłanianie żelaza wzrasta o $20-40 \%$, zależnie od stopnia niedoboru. W I trymestrze zapotrzebowanie dobowe jest niewielkie i wynosi 1-2 mg żelaza, natomiast w III trymestrze wzrasta do $6 \mathrm{mg}$ /dobę. Całkowite zapotrzebowanie na żelazo w czasie ciąży wynosi od 900 do $1200 \mathrm{mg}$; 500-600 mg jest wykorzystywane $\mathrm{w}$ hematopoezie u matki, 80$-100 \mathrm{mg}$ stanowi depozyt łożyskowy, a około $225 \mathrm{mg}$ wykorzystują tkanki płodu. Średnia utrata żelaza w czasie porodu jest równa $250 \mathrm{mg}$. Zawartość żelaza w mleku matki wynosi $0,75-1 \mathrm{mg} / 1$. Prawidłowo zachowana gospodarka żelazem warunkuje prawidłowy przebieg ciąży, natomiast niedobór sprzyja porodom przedwczesnym i niskiej masie urodzeniowej noworodka [3, 4].

Kobiety $z$ niskim stężeniem ferrytyny $(<12 \mathrm{ng} /$ $/ \mathrm{ml}$ ) powinny przyjmować żelazo elementarne w ilości $60-65 \mathrm{mg} /$ dobę. Przy tej dawce $\mathrm{z}$ przewodu pokarmowego wchłania się średnio $6 \mathrm{mg}$ żelaza; podwojenie dawki zwiększa wchłanianie do $10 \mathrm{mg}$. Dalsza eskalacja dawki nie zwiększa istotnie wchłaniania. Leczenie powinno spowodować wzrost stężenia hemoglobiny o 2,0 g/dl w ciągu 3 tygodni. Każda kobieta w ciąży w III trymestrze powinna profilaktycznie przyjmować $30 \mathrm{mg}$ żelaza dziennie. Leczenie pozajelitowymi preparatami żelaza zaleca się w przypadkach zaburzeń jego wchłaniania $z$ przewodu pokarmowego, rzeczywistej nietolerancji preparatów doustnych oraz konieczności szybkiego uzupełnienia niedoborów (dotyczy kobiet w późnym okresie ciąży $z$ głęboką niedokrwistością $z$ niedoboru żelaza) [3-7].

Planując ciążę, kobieta powinna rozpocząć przyjmowanie kwasu foliowego w dawce $400 \mu \mathrm{g} /$ /dobę 12 tygodni przed planowaną ciążą i kontynuować suplementację przez pierwsze 12 t.c. Zwiększone zapotrzebowanie na kwas foliowy występuje $\mathrm{u}$ kobiet $\mathrm{z}$ ciążą wielopłodową, $\mathrm{w}$ niedokrwistościach hemolitycznych, u palących tytoń i u kobiet przyjmujących leki przeciwpadaczkowe. Większe dawki kwasu foliowego są zalecane kobietom, które wcześniej urodziły dziecko $z$ wadą układu nerwowego $[4,6,8]$.

Zapotrzebowanie płodu na witaminę $\mathrm{B}_{12}$ wynosi $50 \mu \mathrm{g}$, co w niewielkim stopniu zmniejsza zapasy matki. U 10-28\% kobiet $z$ prawidłowo przebiegającą ciążą stwierdza się nieznaczne zmniejszenie stężenia witaminy $\mathrm{B}_{12} \mathrm{w}$ surowicy wynikające $z$ hemodylucji, czemu nie towarzyszy niedokrwistość. Grupą osób, u których często obserwuje się niedobór kobalaminy, są wegetarianie (zwłaszcza weganie), dlatego w okresach ciąży i karmienia piersią wskazana jest doustna suplementacja. Chore $z$ rozpoznaną przed ciążą niedokrwistością Addisona-Biermera wymagają kontynuacji przewlekłej podaży witaminy $\mathrm{B}_{12}$ domięśniowo, zazwyczaj w dawce $1000 \mu \mathrm{g}$ co 4-6 tygodni [5, 8].

Najczęściej występującą w polskiej populacji wrodzoną niedokrwistością hemolityczną jest sferocytoza wrodzona. Choroba zwiększa ryzyko wczesnych poronień. U kobiet, u których nie wykonano wcześniej splenektomii, w czasie ciąży częściej obserwuje się nasilenie hemolizy i przełomy hemolityczne, częściej zachodzi równiė konieczność przetaczania koncentratu krwinek czerwonych (kkcz). Wskazane jest przetaczanie kkcz zgodnego fenotypowo w układach Rh i Kell, aby zapobiec alloimmunizacji poprzetoczeniowej i ewentualnego zaistnienia matczyno-płodowego konfliktu serologicznego. W ciągu $10-14$ dni po każdej transfuzji należy wykonać badanie na obecność alloprzeciwciał odpornościowych przeciw krwinkom czerwonym. Aby uniknąć powikłań hematologicznych w czasie ciąży, u kobiet $\mathrm{z}$ rozpoznaną sferocytozą wrodzoną zaleca się splenektomię jeszcze przed planowaną ciążą [9-11].

Niedokrwistość autoimmunohemolityczna (AIHA, autoimmune hemolytic anemia) rzadko jest obserwowana u kobiet w ciąży. Choroba może 
się ujawnić w okresie ciąży lub być rozpoznana wcześniej. Badania immunologiczne mogą ujawnić obecność autoprzeciwciał zarówno typu ciepłego, jak i zimnego. U pacjentek, u których chorobę rozpoznano przed ciążą, może dojść do zaostrzenia hemolizy lub nawrotu choroby, dlatego konieczne są częstsze kontrole morfologii krwi. Badania wykonuje się średnio co 2-3 tygodnie przez okresy ciąży i połogu. W przypadku obecności autoprzeciwciał w klasie immunoglobulin $\mathrm{G}$ (IgG), Ig przechodzących przez łożysko do płodu, wskazana jest okresowa ocena metodami nieinwazyjnymi (badanie doplerowskie szybkości przepływu krwi w tętnicy centralnej mózgu płodu) ewentualnej niedokrwistości u płodu. Celem leczenia jest utrzymanie stężenia hemoglobiny powyżej $9,0 \mathrm{~g} / \mathrm{dl}(>10,0 \mathrm{~g} / \mathrm{dl}$ w I trymestrze) i liczby krwinek czerwonych ponad 3,0 T/1 (optymalnie $>3,5 \mathrm{~T} / \mathrm{l}$ ). W terapii stosuje się glikokortykoidy, dożylne Ig (IVIG, intravenous immunoglobulin) i przetoczenia kkcz zgodnych fenotypowo [12-14].

\section{Małopłytkowości}

Małopłytkowość komplikuje przebieg 7-12\% ciąż, $75 \%$ przypadków stanowi małopłytkowość kobiet w ciąży (małopłytkowość indukowana ciąża), 15-20\% to wtórne małopłytkowości w przebiegu innych chorób wewnętrznych i powikłań położniczych (np. nadciśnienia tętniczego indukowanego ciążą, stanu przedrzucawkowego, zespołów mikroangiopatii zakrzepowych i zakażeń), 3-4\% przypadków to małopłytkowości immunologiczne, a 1-2\% stanowią rzadkie małopłytkowości wrodzone $[1,2]$.

Cele postępowania diagnostyczno-leczniczego w przypadku małopłytkowości u kobiety w ciąży są następujące: 1) ustalenie przyczyny małopłytkowości; 2) ocena zagrożenia stwarzanego przez małopłytkowość dla matki i dziecka; 3) ustalenie optymalnego postępowania zapewniającego bezpieczeństwo matce $\mathrm{w}$ czasie ciąży, porodu i połogu oraz dziecku $[15,16]$.

\section{Małopłytkowość indukowana ciążą}

Zmniejszenie liczby PLT, podobnie jak niedokrwistość kobiet w ciąży, jest zjawiskiem fizjologicznym, wynikającym $z$ hemodylucji, zwiększonego rozpadu krwinek płytkowych w przebiegu hiperkinetycznego krążenia i prawdopodobnie hormonalnego zahamowania płytkotworzenia. Małopłytkowość indukowana ciążą występuje $\mathrm{u}$ zdrowych kobiet $z$ prawidłowo przebiegającą ciążą, a stopniowe zmniejszanie liczby PLT obserwuje się w II i III trymestrze. U 97\% kobiet liczba
PLT utrzymuje się powyżej $50 \mathrm{G} / 1$, co zapewnia hemostazę u matki na okresy ciąży i porodu. O sposobie zakończenia ciąży decydują wskazania położnicze. Cechą charakterystyczną jest tendencja do nawracania małopłytkowości w kolejnych ciążach. Małopłytkowość indukowaną ciążą nie wiąże się ze zwiększonym ryzykiem urodzenia dziecka $z$ małopłytkowością [17].

Różnicowanie między małopłytkowością indukowaną ciążą a pierwotną małopłytkowością immunologiczną (PIT, primary immune thrombocytopenia) jest bardzo trudne, a niekiedy wręcz niemożliwe. O ostatecznym rozpoznaniu decyduje czas — brak normalizacji liczby PLT po porodzie lub nawrót małopłytkowości w ciągu 6 miesięcy po porodzie przesądza o rozpoznaniu PIT. Należy zaznaczyć, że obecność przeciwciał przeciwpłytkowych nie jest specyficzna dla PIT; ich występowanie niekiedy obserwuje się u zdrowych kobiet w ciąży, u których nie stwierdza się małopłytkowości i u kobiet z małopłytkowością indukowaną ciążą. Celem wykonania badań immunologicznych jest wykrycie alloprzeciwciał przeciwpłytkowych, które mogą odpowiadać za alloimmunologiczną małopłytkowość płodowo-noworodkową, a nie samo stwierdzenie obecności autoprzeciwciał $[15,17,18]$.

Pierwotna małopłytkowość immunologiczna

Pierwotna małopłytkowość immunologiczna występuje $z$ częstością 1-2 przypadków na 1000 porodów. Choroba może się ujawnić na każdym etapie ciąży, najczęściej jednak występuje w jej pierwszej połowie. U kobiety w okresie całkowitej remisji (CR) choroby, uzyskanej farmakoterapią lub w wyniku splenektomii, może dojść do nawrotu, a jego ryzyko nie zależy od czasu trwania remisji ani sposobu, w jaki ją uzyskano.

Pacjentki bez objawów $z$ liczbą PLT powyżej $30 \mathrm{G} / 1$ nie wymagają leczenia w I i II trymestrze, konieczna jest jedynie częstsza kontrola, co 7-14 dni. Leczenia wymagają kobiety w ciąży $z$ liczbą PLT ponizej $30 \mathrm{G} / 1$ z objawami skazy krwotocznej, wspólistniejącą dysfunkcją PLT lub gdy konieczne jest przeprowadzenie inwazyjnych procedur położniczych. Po 34-36 t.c. celem leczenia jest osiągnięcie liczby PLT powyżej 50 G/l. Podstawowymi lekami w terapii małopłytkowości są glikokortykosteroidy i IVIG. Glikokortykosteroidy stanowią pierwszą linię leczenia, tym niemniej w przypadku długotrwałej terapii występuje dużo działań niepożądanych, w tym zaburzenia tolerancji glukozy, nadciśnienie tętnicze, zaburzenia elektrolitowe czy psychozy poporodowe. Ponadto wzrasta ryzyko przedwczesnego pęknięcia błon płodowych 
i odklejenia łożyska. W leczeniu steroidami kobiet w ciąży zalecane są minimalne dawki efektywne, utrzymujące liczbę PLT w granicach hemostatycznych. Dożylne immunoglobuliny najczęściej wykorzystuje się w leczeniu małopłytkowości we wczesnym okresie ciąży lub jako przygotowanie do porodu. W przypadku konieczności wykonania splenektomii optymalnym okresem jest II trymestr ciąży - około 20 t.c. Inne leki, takie jak azatiopryna, rytuksymab czy winkrystyna, są rzadko stosowane $\mathrm{w}$ terapii małopłytkowości u kobiet w ciąży i nie powinny być stosowane w I trymestrze [18-21]. Sposób zakończenia ciąży zależy od wskazań położniczych. Cięcie cesarskie należy rozważyć w przypadkach wysokiego ryzyka urodzenia dziecka $z$ ciężką małopłytkowością, na przykład współistnienia alloimmunologicznej małopłytkowości płodowo-noworodkowej i w przypadkach, gdy kobieta wcześniej urodziła dziecko $\mathrm{z}$ głęboką małopłytkowością [15, 18-21].

\section{Małopłytkowości wrodzone (rodzinne)}

Dokładnie zebrany wywiad pozwala ustalić rodzinny charakter występowania choroby, stopień jej nasilenia i oszacować ryzyko powikłań krwotocznych. W niektórych przypadkach skaza małopłytkowa może mieć charakter złożony; zaburzeniom ilościowym towarzyszą zaburzenia czynnościowe PLT. Ciąża najczęściej powoduje pogłębienie małopłytkowości, a najniższa liczba PLT przypada na II i III trymestr ciąży. Po porodzie liczba ta powraca do wartości sprzed ciąży. Postępowaniem $z$ wyboru w okresie okołoporodowym jest przetaczanie koncentratów krwinek płytkowych.

U części chorych z zaburzeniami czynnościowymi PLT, by skrócić krwawienie, można zastosować desmopresynę (deamino-D-argininowazopresynę [DDAVP, desamino-D-arginine vasopressin) $\mathrm{w}$ dawce $0,3 \mu \mathrm{g} / \mathrm{kg} \mathrm{mc}$. w 30-minutowym wlewie bezpośrednio przed porodem lub po nim. Lek jest nieskuteczny w trombastenii Glanzmanna i zespole Scotta [15, 22, 23].

\section{Noworodek matki z małopłytkowością}

Zmniejszenie liczby PLT obserwuje się u około $1 \%$ zdrowych noworodków i u 3-4\% noworodków urodzonych przez matki z małopłytkowością indukowaną ciążą. W większości przypadków zmniejszenie liczby PLT jest niewielkie i dzieci nie wymagają leczenia. $Z$ kolei u noworodków matek chorych na PIT zmniejszenie liczby PLT występuje w $20-40 \%$ przypadków, w tym u $10 \%$ dzieci liczba PLT jest obniżona poniżej $50 \mathrm{G} / 1$, natomiast u 0,5-1\% dochodzi do wylewu śródczaszkowego.
Nie stwierdza się zależności między liczbą PLT u matki, obecnością czy brakiem przeciwciał u matki a liczbą PLT u płodu/noworodka [24, 25].

U każdego noworodka urodzonego przez matkę z małopłytkowością (niezależnie od etiologii) wskazana jest kontrola PLT w 1 . dobie życia. Jeśli wynik jest prawidłowy, to badanie należy powtórzyć między 3. a 6 . dobą życia, ponieważ u około $25 \%$ dzieci małopłytkowość ujawnia się z opóźnieniem. $\mathrm{W}$ przypadku wysokiego ryzyka wystąpienia małopłytkowości u płodu/noworodka wskazana jest regularna ocena ultrasonograficzna (USG) struktur mózgowych u płodu, począwszy od 20. t.c. (u zdrowego płodu liczba PLT stabilizuje się w okolicach 18.-20. t.c.), po porodzie zaś zaleca się wykonanie przezciemiączkowego badaniu USG mózgu, nawet w przypadku braku objawów skazy krwotocznej i prawidłowej liczby PLT [15, 24, 25].

\section{Choroby nowotworowe ulkładów krwiotwórczego i chłonnego}

Chorobę nowotworową rozpoznaje się w przebiegu jednej na 1000-2000 ciąż. Najczęściej występującymi nowotworami w tym okresie są: rak piersi, rak szyjki macicy, chłoniak Hodgkina (HL, Hodgkin lymphoma), czerniak, białaczka i chłoniaki nie-Hodgkina (NHL, non-Hodgkin lymphoma) [26]. $Z$ jednej strony prezentacja choroby jest taka sama jak w populacji ogólnej, choć ciąża może maskować niektóre objawy i spowodować opóźnienie rozpoznania. $Z$ drugiej strony ciąża może się przyczynić do szybszego wykrycia choroby, zwłaszcza zlokalizowanej w narządzie rodnym. Podstawą rozpoznania jest badanie histologiczne, a ciąża nie stanowi przeciwwskazania do wykonania biopsji zajętego narządu, w tym biopsji węzła chłonnego i trepanobiopsji szpiku. Wykonanie zabiegu w znieczuleniu miejscowym jest bezpieczne w każdym okresie ciąży, natomiast pobranie materiału do badania histopatologicznego w znieczuleniu ogólnym jest bezpieczne po uplywie I trymestru [26-28].

Badania USG i badanie metodą rezonansu magnetycznego (bez kontrastu) nie wiążą się $z$ ryzykiem napromienienia płodu i można je wykonać na każdym etapie ciąży. Rutynowe badania radiologiczne, w tym tomografia komputerowa bez użycia kontrastu, nie zwiększają ryzyka wad wrodzonych, ponieważ dawki są o wiele niższe (8$-30 \mathrm{mGy}$ ) od uznanych za niebezpieczne (>100 mGy). W czasie ciąży należy unikać wykonywania badań radiologicznych $z$ podaniem kontrastu, pozytonowej tomografii emisyjnej i badań $z$ użyciem izotopów promieniotwórczych. W okresie laktacji, 
w przypadku konieczności wykonania badania $z$ kontrastem, pacjentka musi przerwać karmienie piersią na 48 godzin, ponieważ nawet niewielka ilość kontrastu przenika do mleka [26, 29].

Stosowanie leków cytostatycznych w okresie ciąży wiąże się z ryzykiem wystąpienia działań niepożądanych. Większość tego typu leków ma masę molekularną $250-400 \mathrm{kDa}$ i łatwo pokonuje barierę łożyskową, przedostając się do tkanek płodu. $Z$ kolei wpływ chemioterapii na rozwijający się płód zależy od okresu podawania leków. Ich stosowanie $\mathrm{w}$ fazie preembrionalnej (od zapłodnienia do 17 . dnia ciąży), kiedy podział komórek jest bardzo dynamiczny, najczęściej prowadzi do poronienia, jeżeli jednak ciąża się utrzyma, to najprawdopodobniej odległe efekty nie wystąpią. Chemioterapia stosowana w okresie organogenezy, między 2. a 8. t.c., może uszkadzać takie narządy, jak serce, cewa nerwowa, kończyny, a efekt jej działania jest nieodwracalny. Prowadzi do powstania dużych wad wrodzonych w $10-20 \%$ przypadków. W okresie płodowym (8.-38. t.c.) dominuje wzrost, ale rozwijają się również przewód pokarmowy i kora mózgowa. Ryzyko powstania wad indukowanych chemioterapią przeciwnowotworową stosowaną w tym okresie jest niewielkie i akceptowalne. Najczęstszymi działaniami niepożądanym są zahamowanie wzrostu wewnątrzmacicznego płodu, poród przedwczesny i obumarcie wewnątrzmaciczne płodu [28-31].

Podczas stosowania leków u pacjentki w ciąży należy uwzględnić zmiany w metabolizmie tych substancji wynikające ze zmian fizjologicznych zachodzących w tym okresie. Hemodylucja, zmniejszone stężenia albumin, zwiększony klirens nerkowy i wątrobowy zmieniają metabolizm leków, szybkość ich wydalania oraz biodostępność [26, 27].

Poród u pacjentek leczonych cytostatycznie w czasie ciąży należy planować 3-4 tygodnie po podaniu ostatniego kursu chemioterapii, co daje czas na odnowę szpiku u matki oraz eliminację leków $z$ tkanek płodu. O sposobie zakończenia ciąży decydują wskazania położnicze. W każdym przypadku choroby nowotworowej u matki należy zbadać łożysko i sznur pępowinowy pod kątem obecności komórek nowotworowych. W białaczkach wskazana jest również kontrola krwi noworodka (może to być krew pępowinowa) na obecność komórek białaczkowych [29, 32-34].

Jest mało danych na temat wpływu przeciwciał monoklonalnych na przebieg ciąży i rozwijający się płód. Większość tych przeciwciał należy do klasy IgG1 - są to w większości duże hydrofilne cząsteczki, które nie mają zdolności przenikania przez łożysko na zasadzie swobodnej dyfuzji. U dzieci matek leczonych w czasie ciąży rytuksymabem nie obserwowano wad wrodzonych ani zwiększonej zapadalności na zakażenia. Dzieci prawidłowo odpowiadały na szczepienia, mimo że u niektórych obserwowano supresję limfocytów B, która utrzymywała się przez 4-6 miesięcy [32].

Wpływ czynników wzrostu kolonii granulocytów na ciążę nie jest znany, aczkolwiek na modelach $z$ wierzęcych udowodniono, że cytokina przechodzi przez łożysko i prowokuje powstanie obwodowej neutrofilii i zwiększone pulowanie neutrofili w śledzionie i szpiku płodu. Przenikanie cytokiny do mleka matki jest ograniczone. Wydaje się jednak, że lek jest bezpieczny w okresach ciąży i połogu. W dotychczasowym piśmiennictwie nie opisano istotnych powikłań przebiegu ciąży u kobiet przyjmujących czynnik wzrostu kolonii granulocytów [30].

Zastosowanie radioterapii u kobiet w ciąży jest ograniczone. Dopuszcza się napromienianie guza zlokalizowanego w okolicach odległych od macicy, na przykład radioterapię ośrodkowego układu nerwowego (OUN) czy nadprzeponowych węzłów chłonnych. Konieczne jest wtedy zastosowanie odpowiednich osłon ochraniających płód [30].

\section{Ostre białaczki}

Ostre białaczki wikłają przebieg jednej na 10000 ciąż. Dominują ostre białaczki szpikowe, które stanowią $2 / 3$ zachorowań. Około $23 \%$ rozpoznań jest dokonywanych w I trymestrze, 37\% w II, a $40 \%$ w III trymestrze ciąży. Rozpoznanie ostrej białaczki u kobiety w ciąży wiąże się z koniecznością wyboru postępowania, które będzie optymalne dla matki i rozwijającego się płodu. Rozpoznanie choroby w I trymestrze wymusza rozważenie zakończenia ciąży, ponieważ zastosowanie chemioterapii w tym okresie wiąże się $z$ wysokim ryzykiem dużych wad wrodzonych u płodu i powikłaniami krwotocznymi u matki. Stosowanie chemioterapii w II i III trymestrze jest stosunkowo bezpieczne [34, 35].

Arabinozyd cytozyny podawany we wczesnym okresie ciąży może spowodować powstanie wad układu kostnego u płodu, $z$ kolei antybiotyki antracyklinowe wpływają na uszkodzenie mięśnia sercowego. W pojedynczych doniesieniach obserwowano ostrą niewydolność krążenia u płodów po lekach podanych matce - w części przypadków zmiany były odwracalne. $\mathrm{W}$ trakcie stosowania chemioterapii zawierającej leki kardiotoksyczne należy regularnie kontrolować echokardiograficznie serce płodu [34, 35].

Preferuje się poród naturalny, ponieważ cięcie cesarskie stwarza wyższe ryzyko powikłań krwotocznych. Jeżeli w czasie ciąży stosowano antybiotyki 
antracyklinowe, to po porodzie konieczne jest dalsze monitorowanie kardiologiczne noworodka.

Łożysko nie jest doskonałą barierą dla komórek białaczkowych. Komórki białaczkowe matki, które przeniknęły do krwioobiegu płodu w ciągu 6 tygodni po porodzie, powinny być zniszczone przez układ immunologiczny dziecka [33-35].

\section{Przewlekła białaczka szpikowa}

Częstość współistnienia ciąży z przewlekłą białaczką szpikową (CML, chronic myelogenous leukemia) oceniono na jeden na 75000 porodów. Choroba zwiększa ryzyko niewydolności łożyska (zakrzepy, leukostaza, zawały łożyska), co może skutkować zahamowaniem wzrostu wewnątrzmacicznego płodu, obumarciem płodu, przedwczesnym odklejeniem łożyska, stanem przedrzucawkowym czy porodem przedwczesnym. Stosowane powszechnie inhibitory kinazy tyrozynowej (TKI, tyrosine kinase inhibitors) BCR/ABL1 działają teratogennie. Doświadczenia zebrane na podstawie obserwacji przebiegu ciąż u kobiet leczonych imatynibem wskazują na prawdopodobieństwo zwiększenia częstości wad wrodzonych u płodu. Odsetek takich wad u dzieci matek przyjmujących imatynib w czasie ciąży oceniono na 9,6\%; większość stanowiły dzieci kobiet leczonych w I trymestrze ciąży. Zwracał uwagę duży odsetek wad układu kostnego (niezrośnięte kręgi, przedwcześnie zarośnięte szwy czaszkowe, anomalie kości ramiennej, przepuklina mózgowa) [36]. $Z$ tego względu imatynib i inne TKI nie mogą być bezpiecznie stosowane w ciąży, zwłaszcza w okresie organogenezy. Zalecane postępowanie obejmuje leukaferezy i stosowanie interferonu $\alpha$ (IFN $\alpha)$. W mleku kobiet przyjmujących imatynib obecny jest jego metabolit — CPG74588 - i śladowe stężenia leku, dlatego karmienie piersią jest przeciwwskazane [36, 37].

Stwierdzono, że dzieci mężczyzn leczonych imatynibem rozwijają się prawidłowo. Dlatego u mężczyzn nie zaleca się przerywania terapii tym lekiem w okresie starań o poczęcie dziecka [36].

\section{Nadpłytkowość samoistna}

W czasie ciąży dochodzi do samoistnego zmniejszenia liczby PLT o 20-44\% wartości sprzed okresu ciąży. Powikłania zakrzepowe występują w przebiegu 2-5\% ciąż. Powikłania krwotoczne, stwierdzane najczęściej przy liczbie PLT powyżej 1500 G/l, wikłają przebieg 4-9\% ciąż. Choroba sprzyja powikłaniom położniczym, takim jak: poronienia (31\% ciąż), stan przedrzucawkowy, nadciśnienie tętnicze indukowane ciążą, zahamo- wanie wewnątrzmaciczne wzrostu płodu (4-5\% ciąż), przedwczesne odklejenie łożyska ( $2 \%$ ciąż), wewnątrzmaciczne obumarcie płodu (4-7\% ciąż). Najczęściej są one wynikiem zakrzepicy naczyń łożyska, rzadziej wylewów podłożyskowych. $\mathrm{W}$ ostatnich doniesieniach sugeruje się, że obecność mutacji JAK2 V617F zwiększa ryzyko utraty płodu i powikłań zakrzepowych, choć nie udowodniono ścisłej zależności w tym względzie.

Kobiety leczone cytoredukcyjnie, planujące ciążę, powinny 3-6 miesięcy przed ciążą odstawić hydroksykarbamid i anagrelid. Lekiem $z$ wyboru $\mathrm{w}$ cytoredukcji w okresie okołokoncepcyjnym i ciąży jest IFN $\alpha$. U większości pacjentek leczonych przed ciążą IFN $\alpha$ w czasie ciąży konieczna jest kontynuacja leczenia, ale w zmniejszonej dawce. W profilaktyce przeciwzakrzepowej rekomenduje się kwas acetylosalicylowy (ASA, acetylsalicylic acid) w dawce $75 \mathrm{mg} /$ dobę. Podawanie leku należy przerwać 2 tygodnie przed planowanym porodem, a w okresach okołoporodowym i połogu zastosować heparyny drobnocząsteczkowe. W okresie połogu należy stosunkowo często kontrolować liczbę PLT, ponieważ w krótkim czasie po porodzie ich liczba powraca do wartości sprzed ciąży, a często nawet ją przekracza [38, 39].

\section{Czerwienica prawdziwa}

Czerwienica prawdziwa sprzyja powikłaniom położniczym - odsetek samoistnych poronień ocenia się na $36 \%$, a obumarć wewnątrzmacicznych na $8 \%$. Częściej występują nadciśnienie tętnicze indukowane ciążą i stan przedrzucawkowy. Za pomocą krwioupustów należy utrzymywać wartości hematokrytu w granicach charakterystycznych dla danego okresu ciąży. W przypadku konieczności zastosowania leczenia cytoredukcyjnego lekiem $z$ wyboru jest IFN $\alpha$, a w profilaktyce przeciwzakrzepowej zaleca się stosowanie ASA [40, 41]. Podobnie jak w przypadku nadpłytkowości samoistnej podawanie leku należy przerwać 2 tygodnie przed planowanym porodem, a w okresach okołoporodowym i połogu zastosować heparyny drobnocząsteczkowe.

\section{Nowotwory układu chłonnego}

Częstość rozpoznawania NHL w czasie ciąży ocenia się na jeden przypadek na 1000-6000 ciąż, HL zaś - na jeden przypadek na 1000-3000 ciąż. Chłoniaki agresywne stanowią $76 \%$ przypadków, $\mathrm{w}$ tym $56 \%$ chłoniaki rozlane $z$ dużych komórek B, a $20 \%$ chłoniaki T-komórkowe. W 40\% przypadków w chwili rozpoznania chorobę cechuje III lub IV stopień zaawansowania klinicznego. Ponad jedna lokalizacja pozawęzłowa dotyczy $26 \%$ chorych. 
Zwiększona częstość występowania nacieków w układzie rozrodczym może być wynikiem działania hormonów i zwiększonego przepływu krwi przez te organy. Chłoniaki indolentne rzadko są obserwowane u kobiet w ciąży. Przebieg kliniczny NHL jest zazwyczaj typowy i nie wpływa niekorzystnie na ciążę, a sama ciąża nie zmienia przebiegu choroby. Rozpoznanie choroby we wczesnym okresie ciąży zmusza do rozważenia jej przerwania lub odroczenia leczenia do zakończenia I trymestru. Po upływie 12. t.c. można zastosować standardowe leczenie systemowe [30, 42-44].

\section{Ciąża po przebytym leczeniu przeciwnowotworowym}

Odległym działaniem niepożądanym leków cytostatycznych jest uszkodzenie gonad i mięśnia macicy. Do przedwczesnej niewydolności jajników (POF, premature ovarian failure) dochodzi u $13 \%$ kobiet poniżej 20. roku życia i u ponad $50 \%$ w wieku powyżej 35 lat poddanych chemioterapii przeciwnowotworowej. Oprócz wieku istotnymi czynnikami ryzyka POF są rodzaj zastosowanych leków i ich dawki kumulacyjne. Największy gonadotropizm wykazują leki z grupy alkilujących (cyklofosfamid, prokarbazyna). Radioterapia okolic miednicy małej uszkadza zarówno tkankę jajnika, jak i mięsień macicy. Uszkodzenie jajników pod wpływem promieniowania jest efektem dawkozależnym, dużą rolę odgrywa też wiek pacjentki. Dawka letalna dla ludzkiego oocytu $\left(\mathrm{LD}_{50}\right)$ wynosi $4 \mathrm{~Gy}$. Zmniejszona kurczliwość uszkodzonego mięśnia macicy może tłumaczyć zwiększony odsetek ciąż zakończonych cięciem cesarskim w tej grupie kobiet. Radioterapia obejmująca OUN, $z$ powodu uszkodzenia osi przysadka-podwzgórze, może być kolejną przyczyną niewydolności jajników. Dotychczasowe doświadczenia nie wskazują, aby istniała skuteczna farmakologiczna metoda ochraniająca gonady przed toksycznym działaniem leków przeciwnowotworowych [45-47].

Ciąża u kobiety, która w przeszłości przebyła leczenie przeciwnowotworowe, jest coraz częściej spotykaną sytuacją w praktyce położniczej. Taką ciążę powinien prowadzić zespół wielodyscyplinarny. W każdym przypadku, zwłaszcza jeżeli w trakcie leczenia choroby nowotworowej konieczne było przetaczanie składników krwi i preparatów krwiopochodnych, należy wykluczyć alloimmunizację potransfuzyjną, która może odpowiadać za chorobę hemolityczną u płodu/noworodka lub allogeniczną małopłytkowość płodowo-noworodkową. Wskazana jest też okresowa kontrola funkcji tarczycy (zwłasz- cza w okresach zwiększonego zapotrzebowania na hormony), ze względu na zwiększone ryzyko subklinicznej niedoczynności tarczycy. W przypadkach, w których chemioterapia zawierała leki antracyklinowe, wskazana jest ocena echokardiograficzna serca, najlepiej przeprowadzona w okresie największego obciążenia układu krążenia (28-32 t.c.) i przed porodem. Odsetek wad wrodzonych u dzieci matek, które przebyły leczenie przeciwnowotworowe, jest zbliżony do odsetka w zdrowej populacji i ocenia się go na około 3\% [45-47].

\section{Podsumowanie}

Choć przebieg kliniczny większości chorób hematologicznych jest taki sam, jak w populacji ogólnej, to zmiany fizjologiczne zachodzące w okresie ciąży mogą maskować niektóre objawy i przyczyniać się do opóźnienia rozpoznania. Rozpoznanie i leczenie chorób hematologicznych, które wystąpiły w czasie ciąży, są trudne i nierzadko wymagają zaangażowania wielu specjalistów: hematologa, onkologa, położnika, anestezjologa, neonatologa czy psychologa. W każdym przypadku celami postępowania diagnostyczno-leczniczego są jak najszybsze ustalenie rozpoznania, ocena zagrożenia stwarzanego przez chorobę dla matki i dziecka oraz ustalenie optymalnego postępowania, które zapewni bezpieczeństwo matce w czasie ciąży, porodu i połogu oraz dziecku.

\section{Piśmiennictwo}

1. Paidas M.J., Hassain N. Hematologic changes in pregnancy w hemostasis thrombosis obstetrics gynecology. W: Paidas M.J., Hassain N., Shamsi T.S. i wsp. (red.). Hemostasis and thrombosisin obstetrics \& gynecology. Wiley-Blackwell, Oxford 2010: 1-11.

2. Duffy T.P. Hematologic aspects of pregnancy. W: Hoffman R., Benz E.J., Shattil S.J., Furie B., Cohen H.J., Silberstein L.E., McGlave P. (red.). Hematology. Basic principles and practice. Churchil Livingstone, New York, Edinburgh, London, Philadelphia, San Francisco 2000: 2375.

3. Pavord S., Myers B., Robinson S., Allard S., Strong J., Oppenheimer C.; on behalf of the British Committee for Standards in Haematology: UK guidelines on the management of iron deficiency in pregnancy. Br. J. Haematol. 2012; 156: 588-600.

4. Yakoob M.Y., Bhutta Z.A. Effect of routine iron supplementation with or without folic acid on anemia during pregnancy. BMC Public Health 2011; 11: S21.

5. Townsley D.M. Hematologic complications of pregnancy. Semin. Hematol. 2013; 50: 222-231.

6. Baker W.F., Lee R. Iron deficiency, folate, and vitamin B12 deficiency in pregnancy, obstetrics, and gynecology. W: Bick R.L., Frenkel E.P., Baker W.F., Sarode R. (red.). Hematological complications in obstetrics, pregnancy and gynecology. Cambridge University Press, Cambridge 2006: 269-309. 
7. Gaillard R., Eilers P.H., Yassine S. i wsp. Risk factors and consequences of maternal anaemia and elevated haemoglobin levels during pregnancy: a population-based prospective cohort study. Pediatr. Perinat. Epidemiol. 2014; 28: 213-226.

8. Devalia V., Hamilton M.S., Molloy A.M.; the British Committee for Standards in Haematology. Guidelines for the diagnosis and treatment of cobalamin and folate disorders. Br. J. Haematol. 2014; 166: 496-513.

9. Bolton-Maggs P.H., Langer J.C., Iolascon A., Tittensor P., King M.J. Guidelines for the diagnosis and management of hereditary spherocytosis - 2011 update. Br. J. Haematol. 2012; 156: 37-49.

10. Nordvall M., Dziegie M., Hegaard H.K. i wsp. Red blood cell antibodies in pregnancy and their clinical consequences: synergistic effects of multiple specificities. Transfusion 2009; 49: 2070-2075.

11. Foudoulaki-Paparizos L., Valsami S., Bournas N. i wsp. Alloimmunisation during pregnancy in Greece: need for nationwide HDFN prevention programme. Transf. Med. 2013; 23: 254-259.

12. Hoppe B., Stibbe W., Bielefeld A., Pruss A., Salama A. Increased RBC autoantibody production in pregnancy. Transfusion 2001; 41: 1559-1561.

13. Meulenbroek E.M., Wouters D., Zeerleder S.S. Lyse or not to lyse: clinical significance of red blood cell autoantibodies. Blood Rev. 2015; 29: 369-376.

14. Lechner K., Jäger U. How I treat autoimmune hemolytic anemias in adults. Blood 2010; 116: 1831-1838.

15. Scully M., Hunt B.J., Benjamin S. i wsp.; on behalf of British Committee for Standards in Haematology: Guidelines on the diagnosis and management of thrombotic thrombocytopenic purpura and other thrombotic microangiopathies. Br. J. Haematol. 2012; 158: 323-335.

16. Gernsheimer T.B. Thrombocytopenia in pregnancy: is this immune thrombocytopenia or...? Hematology 2012; 198-202.

17. McCrae K.R. Thrombocytopenia in pregnancy. Hematology 2010; 397-402.

18. Provan D., Stasi R., Newland A.C. i wsp. International consensus report on the investigation and management of primary immune thrombocytopenia. Blood 2010; 115: 168-186.

19. Gernsheimer T., James A.H., Stasi R. How I treat thrombocytopenia in pregnancy. Blood 2013; 121: 38-47.

20. Sun D., Shehata N., Ye X.Y. i wsp. Corticosteroids compared with intravenous immunoglobulin for the treatment of immune thrombocytopenia in pregnancy. Blood 2016; 128: 1329-1335.

21. Stavrou E., McCrae K.R. Immune trombocytopenia in pregnancy. Hematol. Oncol. Clin. North Am. 2009; 23: 1299-1316.

22. Noris P., Schlegel N., Klersy C. i wsp. Analysis of 339 pregnancies in 181 women with 13 different forms of inherited thrombocytopenia. Haematologica 2014; 99: 1387-1394.

23. Fausett B., Silver R.M. Congenital disorders of platelet function. Clin. Obstet. Gynecol. 1999; 42: 390-405.

24. Koyama S., Tomimatsu T., Kanagawa T. i wsp. Reliable predictors of neonatal immune thrombocytopenia in pregnant women with idiopathic thrombocytopenic purpura. Am. J. Hematol. 2012; 87: 15-21.

25. Chakravorty S., Roberts I. How I treat neonatal trombocytopenia. Br. J. Haematol. 2012; 156: 155-162.

26. Van Calsteren K., Amant F. Cancer during pregnancy. Acta Obstet. Gynecol. Scand. 2014; 93: 443-446.

27. Basta P., Bak A., Roszkowski K. Cancer treatment in pregnant Women. Contemp. Oncol. (Pozn.) 2015; 19: 354-360.

28. Peccatori F.A., Azim H.A. Jr, Orecchia R. i wsp.; ESMO Guidelines Working Group. Cancer, pregnancy and fertility: ESMO Clinical
Practice Guidelines for diagnosis, treatment and follow-up. Ann. Oncol. 2013; 6: 160-170.

29. Vandenbriele C., Dierickx D., Amant F., Delforge M. The treatment of hematologic malignancies in pregnancy. Facts Views Vis. Obgyn 2010; 2: 74-87.

30. Lavi N., Horowitz N.A.S., Brenner B. An update on the management of hematologic malignancies in pregnancy. Women's Health 2014; 10: 255-266.

31. Amant F., Vandenbroucke T., Verheecke M. i wsp.; for the International Network on Cancer, Infertility, and Pregnancy (INCIP). Pediatric outcome after maternal cancer diagnosed during pregnancy. N. Engl. J. Med. 2015; 373: 1824-1834.

32. Avivi I., Farbstein D., Brenner B., Horowitz N. Non-Hodgkin lymphomas in pregnancy: tackling therapeutic quandaries. Blood Rev. 2014; 28: 213-220.

33. Mahmoud H.K., Samra M.A., Fathy G.M. Hematologic malignancies during pregnancy: a review. J. Adv. Res. 2016; 7: 589 -596 .

34. Ali S., Jones G.L., Culligan D.J. i wsp.; on behalf of the British Committee for Standards in Haematology. Guidelines for the diagnosis and management of acute myeloid leukaemia in pregnancy. Br. J. Haematol. 2015; 170: 487-495.

35. Thomas X. Acute myeloid leukemia in the pregnant women. Eur. J. Haematol. 2015; 95: 124-136.

36. Pye S.M., Cortes J., Ault P. i wsp. The effects of imatinib on pregnancy outcome. Blood 2008; 111: 5505-5508.

37. Pistilli B., Bellettini G., Giovannetti E. i wsp. Chemotherapy, targeted agents, antiemetics and growth-factors in human milk: how should we counsel cancer patients about breastfeeding? Cancer Treat. Rev. 2012; 39: 207-211.

38. Harrison C.N., Bareford D., Butt N. i wsp. Guideline for investigation and management of adults and children presenting with a thrombocytosis. Br. J. Haematol. 2010; 149: 352-375.

39. Palandr F., Polverelli N., Ottaviani E. i wsp. Long term follow-up of essential thrombocythemia in young adults: treatment strategies, major thrombotic complications and pregnancy outcomes. A study of 76 patients. Haematologica 2010; 95: 1038-1040.

40. Robinson S., Bewley S., Hunt B.J., Radia D.H, Harrison C.N. The management and outcome of 18 pregnancies in women with polycythemia vera. Haematologica 2005; 90: 147-1483.

41. McMullin M.F., Bareford D., Campbeli P. i wsp. Guidelines for the diagnosis, investigation and management of polycythaemia/ /erythrocytosis. Br. J. Haematol. 2005; 130: 174-204.

42. Bachanova V., Connors J.M. Hodgkin lymphoma in pregnancy. Curr. Hematol. Malig. Rep. 2013; 8: 211-217.

43. Avivi I., Farbstein D., Brenner B., Horowitz N. Non-Hodgkin lymphomas in pregnancy: tackling therapeutic quandaries. Blood Rev. 2014; 28: 213-220.

44. El-Messidi A., Patenaude V. and Abenhaim H.A. Incidence and outcomes of women with non-Hodgkin's lymphoma in pregnancy: a population-based study on 7.9 million births. J. Obstet. Gynaecol. Res. 2015; 41: 582-589.

45. Donnez J., Dolmans M.-M. Preservation of fertility in females with haematological malignancy. Br. J. Haematol. 2011; 154: 175-184.

46. Diller L. Adult primary care after childhood acute lymphoblastic leukemia. N. Engl. J. Med. 2011; 365: 1417-1424.

47. Barton S.E., Najita J.S., Ginsburg E.S. i wsp. Infertility, infertility treatment, and achievement of pregnancy in female survivors of childhood cancer: a report from the Childhood Cancer Survivor Study cohort. Lancet Oncol. 2013; 14: 873-881. 